\title{
Periodontal Disease in Patients Visiting a Tertiary Care Dental Hospital: A Descriptive Cross-sectional Study
}

\author{
Bhageshwar Dhami, ${ }^{1}$ Kamal Babu Thapaliya, ${ }^{2}$ Dinesh Kumar Shrestha, ${ }^{3}$ Bidhan Bhandari, ${ }^{4}$ Sujaya Gupta ${ }^{5}$ \\ 'Department of Periodontics, Kantipur Dental College, Kathmandu, Nepal, ${ }^{2}$ Thapaliya Dental Clinic, Chitwan, \\ Nepal, ${ }^{3}$ Department of Dentistry, Kanti Children's Hospital, Kathmandu, Nepal, ${ }^{4}$ Shree Nobel Dental Home, \\ Kathmandu, Nepal, ${ }^{5}$ Department of Periodontics and Oral Implantology, Kathmandu Medical College, \\ Bhaktapur, Nepal.
}

\section{ABSTRACT}

Introduction: Periodontitis is chronic disease leading to tooth loss. Oral hygiene practices combined with regular dental examinations keep oral cavity disease free and maintain periodontal health. The primary objective was to find out the prevalence of periodontal disease of patients measured by the Simplified Oral Hygiene Index and Community Periodontal Index.

Methods: This descriptive cross-sectional study was conducted in department of Periodontics of a tertiary care dental hospital from April to June 2019 after obtaining ethical clearance and informed consent. Participants were recruited by convenience sampling and 183 sample size was calculated. Proforma included demographics, Simplified Oral Hygiene Index, Community Periodontal Index, body mass index, and smoking status. Data were entered in Statistical Package for Social Sciences version 23 and descriptive statistics were presented as frequency, percentage, mean, and standard deviation.

Results: Prevalence of periodontal disease corresponding to loss of attachment 1, 2, 3, and 4 was found to in 104 (56.83\%) participants. Simplified Oral Hygiene Index score was $1.67 \pm 0.89$ with "fair" status in majority 114 (62.30\%). Gingivitis (Community Periodontal Index 1, 2) was seen in 136 $(74.32 \%)$. The mean age was $36.37 \pm 14.43$ years of which $92(50.27 \%)$ were female but smoking was more in males.

Conclusions: This study suggests deteriorating periodontal health related to age, sex, oral hygiene, smoking, and BMI. As updated information on oral and periodontal health in Nepal is limited, this assessment would help the national policy makers on oral health intervention measures to prevent periodontitis and develop future programs to improve oral health.

Keywords: body mass index; community periodontal index; loss of attachment; oral hygiene index; smoking.

\section{INTRODUCTION}

Oral health related quality of life is associated with periodontal status. ${ }^{1}$ Periodontal disease is chronic disease leading to tooth loss. ${ }^{2-5}$ Oral hygiene practices of regular brushing and flossing of teeth combined with regular dental examinations keep oral cavity healthy. Oral hygiene can be assessed by accumulation of soft and hard deposits on teeth surfaces, the aetiological factors of periodontal diseases. ${ }^{6}$

Using standard tools to assess the oral hygiene status and practices that affect the periodontal health status is essential in formulating appropriate and acceptable dental health services and oral health awareness programs to improve the oral health of the population. ${ }^{2}$ 3,7

The primary objective of the current study was to find the prevalence of periodontal disease of the participants and secondarily to observe the various factors affecting periodontal condition like age, gender,

Correspondence: Dr. Bhageshwar Dhami, Department of Periodontics, Kantipur Dental College, Kathmandu Nepal. Email: dhamibhagesh@gmail.com. Phone: +977-9851068473. 
body mass index (BMI), and oral hygiene methods used by the individuals to maintain their periodontal health.

\section{METHODS}

This single-centre descriptive cross-sectional study was conducted in the Department of Periodontics, Kantipur Dental College from April to June 2019 after obtaining the ethical clearance from the Institutional Review Committee (Ref. 3/2019). Informed consent was obtained before conducting interview and oral examination. The inclusion criteria were male and female individuals over 15 years of age with two or more teeth present in a sextant that were not indicated for extraction. Natural teeth with full coronal restorations and the teeth reduced in height by caries or trauma were excluded. Participants were recruited by convenience (non-probability) sampling and 183 sample size was calculated using formula:

$$
\begin{aligned}
\mathrm{n} & =\mathrm{Z}^{2} \times \mathrm{p} \times(1-\mathrm{p}) / \mathrm{e}^{2} \\
& =1.96^{2} \times 0.862 \times 0.138 / 0.05^{2} \\
& =183
\end{aligned}
$$

where,

$\mathrm{n}=$ minimum required sample size

$Z=1.96$ at $95 \%$ Confidence Interval

$\mathrm{p}=$ prevalence of periodontal disease, $86.27 \%^{8}$

$e=$ margin of error, $5 \%$.

The data were recorded on the proforma based on World Health Organization (WHO) Oral Health Assessment Survey Form. ${ }^{9}$ After a detailed questionnaire, oral hygiene status was assessed using Simplified Oral Hygiene Index (OHI-S) followed by periodontal status using the Community Periodontal Index (CPI)..$^{9,10}$ The dentition was divided into six sextants. Each sextant was assigned a code number and the condition of the worst affected site in that sextant was recorded. The highest CPI and loss of attachment (LOA) scores of any sextant were recorded as the respective CPI and LOA for that individual. The examination was done using mouth mirror, No. 23 explorer (Shepherd's hook) and $\mathrm{CPI}-\mathrm{C}$ probe. The overall $\mathrm{OHI}-\mathrm{S}$ was obtained by adding the two components Simplified Debris Index (DI-S) and the Simplified Calculus Index (Cl-S). OHI-S score was interpreted as: Good (0.0-1.2), Fair (1.3-3.0) and Poor (3.1-6.0).

The BMI values were calculated using standard formula (weight in kilograms divided by the square of height in meters). BMI was categorised as underweight $(<18.5)$, normal weight (18.5-24.9), overweight (25.0-29.9) and obese $(\geq 30) .{ }^{11}$ Smoking behaviour was categorised as current smokers (smoked $\geq 100$ cigarettes in their lifetime and currently smoke), former smokers (smoked $\geq 100$ cigarettes in their lifetime and do not currently smoke) and Non-smokers (not smoked $\geq 100$ cigarettes in their lifetime and do not currently smoke). ${ }^{12}$

Data were entered in Statistical Package for Social Sciences version 23 and analysed. The descriptive statistics were presented as frequency, percentage, mean, standard deviation and standard errors of mean.

\section{RESULTS}

Regarding the overall periodontal status of the 183 participants, 104 (56.83\%) had CPI score of 2 and $84(45.90 \%)$ had LOA score of 1 (Table 1$)$. Healthy periodontal condition CPI 0 was found only in $2(1.09 \%)$ and LOA 0 in $79(43.17 \%)$ of the examined individuals indicating the prevalence of gingival disease (corresponding to CPI 1 and 2) as 136 (74.32\%) and the prevalence of periodontal disease (corresponding to LOA 1, 2, 3 and 4) in 104 (56.83\%) participants (Table 1). The mean values of CPI and LOA scores per sextant with the different age categories in both the sexes are presented (Table 2 and Table 3).

\begin{tabular}{|ll|}
\hline \multicolumn{2}{|l|}{ Table 1. The community periodontal index scores. } \\
\hline CPI score & $\mathbf{n}(\%)$ \\
CPI 0 (healthy) & $2(1.09)$ \\
CPI 1 (bleeding) & $32(17.49)$ \\
CPI 2 (calculus) & $104(56.83)$ \\
CPI 3 (pocket 4-5mm) & $44(24.04)$ \\
CPI 4 (pocket $\geq 6 \mathrm{~mm})$ & $1(0.55)$ \\
CPI X (excluded, < 2 teeth present) & - \\
LOA score & \\
LOA $0(0-3 \mathrm{~mm})$ & $79(43.17)$ \\
LOA $1(4-5 \mathrm{~mm})$ & $84(45.90)$ \\
LOA $2(6-8 \mathrm{~mm})$ & $19(10.38)$ \\
LOA $3(9-11 \mathrm{~mm})$ & $1(0.55)$ \\
LOA $4(\geq 12 \mathrm{~mm})$ & - \\
LOA X (excluded) & - \\
\hline
\end{tabular}

Oral hygiene status as assessed by OHI-S was found to be "fair" in majority $114(62.30 \%)$ of the individuals (Table 4). The mean OHI-S score of the participants was $1.67 \pm 0.89$ (Table 5 ) with mean DI-S score of $0.99 \pm 0.42$ $(\mathrm{SEM}=0.03)$ and mean $\mathrm{Cl}-\mathrm{S}$ score of $0.68 \pm 0.56(\mathrm{SEM}=$ 0.04).

For most participants, it was their first dental visit $(80$, $43.72 \%)$. All of the examined individuals $183(100 \%)$ used toothbrush exclusively to clean their teeth, but only $3(1.64 \%)$ and $4(2.18 \%)$ participants (female individuals in both categories) used interdental aids (dental floss) and mouthwashes respectively (Table 4). Most of them brushed their teeth once a day (127, $69.40 \%$ ) using medium-bristled toothbrushes (106, $57.92 \%)$ and fluoridated toothpaste 180 (98.36\%).

Among 183 individuals, 92 (50.27\%) were females 
Dhami et al. Periodontal Disease in Patients Visiting a Tertiary Care Dental Hospital: A Descriptive Cross-sectional Study...

(Table 4,5$)$. Similar to the pattern of Grewal et al. ${ }^{13}$ all the participants were categorised into three age groups namely $\leq 35$ years, 36 to 55 years, $\geq 56$ years (Table $5)$. Age categories were found to be associated with CPI, LOA, OHI-S and BMI. In $\leq 35$ years, mean scores of $\mathrm{CPI}$ was $1.90 \pm 0.70$, LOA was $0.44 \pm 0.57$, OHI-S was $1.39 \pm 0.81$ and $\mathrm{BMI}$ was $22.11 \pm 3.04$. In 36 to 55 years individuals, the mean values were: $\mathrm{CPI}=2.18 \pm 0.59$, $\mathrm{LOA}=0.82 \pm 0.62, \mathrm{OHI}-\mathrm{S}=1.93 \pm 0.85$ and $\mathrm{BMI}=25.22$ \pm 2 2.69. In participants of $\geq 56$ years, the mean score of CPI was $2.39 \pm 0.72$, LOA was $1.39 \pm 0.66$, OHI-S was $2.22 \pm 0.93$ and $B M I$ was $25.74 \pm 4.39$. The overall mean scores as well as in individual categories are stated in (Table 5). With increasing age, the periodontal status (CPI and LOA scores), oral hygiene status (OHI-S score) and $\mathrm{BMI}$ mean values deteriorated, in both the sexes.

\begin{tabular}{|c|c|c|c|c|}
\hline $\begin{array}{l}\text { CPI } \\
\text { score } \\
\text { per } \\
\text { sextant }\end{array}$ & $\begin{array}{l}\text { Age } \\
\text { group } \\
\text { (years) }\end{array}$ & Sex & Mean \pm SD & SEM \\
\hline \multirow{6}{*}{$17 / 16$} & \multirow[t]{2}{*}{$\leq 35$} & Female & $1.32 \pm 0.91$ & 0.120 \\
\hline & & Male & $1.81 \pm 0.66$ & 0.101 \\
\hline & \multirow[t]{2}{*}{36 to 55} & Female & $1.93 \pm 0.83$ & 0.159 \\
\hline & & Males & $2.09 \pm 0.58$ & 0.101 \\
\hline & \multirow[t]{2}{*}{$\geq 56$} & Female & $2.00 \pm 0.54$ & 0.189 \\
\hline & & Male & $2.47 \pm 0.99$ & 0.256 \\
\hline \multirow{6}{*}{11} & \multirow[t]{2}{*}{$\leq 35$} & Female & $0.61 \pm 0.65$ & 0.086 \\
\hline & & Male & $0.93 \pm 0.67$ & 0.102 \\
\hline & \multirow[t]{2}{*}{36 to 55} & Female & $1.11 \pm 0.93$ & 0.180 \\
\hline & & Male & $1.30 \pm 0.81$ & 0.141 \\
\hline & \multirow[t]{2}{*}{$\geq 56$} & Female & $1.50 \pm 0.76$ & 0.267 \\
\hline & & Male & $1.47 \pm 1.19$ & 0.307 \\
\hline \multirow{6}{*}{$26 / 27$} & \multirow[t]{2}{*}{$\leq 35$} & Female & $1.26 \pm 0.89$ & 0.119 \\
\hline & & Male & $1.77 \pm 0.89$ & 0.137 \\
\hline & \multirow[t]{2}{*}{36 to 55} & Female & $1.78 \pm 0.93$ & 0.180 \\
\hline & & Male & $1.97 \pm 0.74$ & 0.131 \\
\hline & \multirow[t]{2}{*}{$\geq 56$} & Female & $2.00 \pm 0.54$ & 0.189 \\
\hline & & Male & $2.50 \pm 0.86$ & 0.228 \\
\hline \multirow{6}{*}{$36 / 37$} & \multirow[t]{2}{*}{$\leq 35$} & Female & $1.32 \pm 0.85$ & 0.112 \\
\hline & & Male & $1.56 \pm 0.88$ & 0.134 \\
\hline & \multirow[t]{2}{*}{36 to 55} & Female & $1.52 \pm 1.05$ & 0.202 \\
\hline & & Male & $1.91 \pm 0.88$ & 0.153 \\
\hline & \multirow[t]{2}{*}{$\geq 56$} & Female & $2.00 \pm 0.54$ & 0.189 \\
\hline & & Male & $2.270 \pm 1.16$ & 0.300 \\
\hline \multirow{6}{*}{31} & \multirow[t]{2}{*}{$\leq 35$} & Female & $0.81 \pm 0.77$ & 0.101 \\
\hline & & Male & $1.19 \pm 0.79$ & 0.121 \\
\hline & \multirow[t]{2}{*}{36 to 55} & Female & $1.19 \pm 0.89$ & 0.176 \\
\hline & & Male & $1.39 \pm 0.93$ & 0.162 \\
\hline & \multirow[t]{2}{*}{$\geq 56$} & Female & $1.57 \pm 0.79$ & 0.297 \\
\hline & & Male & $2.00 \pm 1.19$ & 0.309 \\
\hline
\end{tabular}

\begin{tabular}{|c|c|c|c|c|}
\hline \multirow{6}{*}{$46 / 47$} & $\leq 35$ & Female & $1.41 \pm 0.85$ & 0.113 \\
\hline & & Male & $1.84 \pm 0.69$ & 0.105 \\
\hline & 36 to 55 & Female & $1.67 \pm 0.92$ & 0.177 \\
\hline & & Male & $2.09 \pm 0.68$ & 0.118 \\
\hline & $\geq 56$ & Female & $2.00 \pm 0.54$ & 0.189 \\
\hline & & Male & $2.29 \pm 1.14$ & 0.304 \\
\hline
\end{tabular}

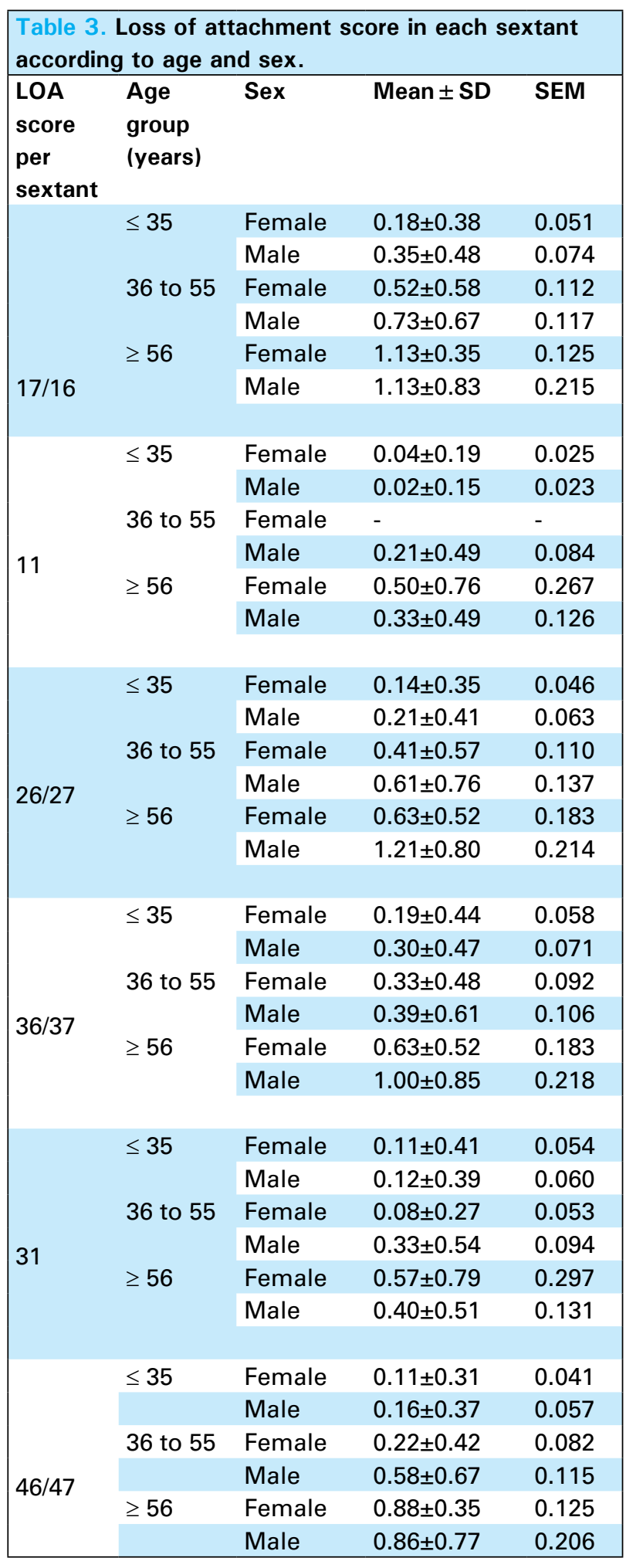


Dhami et al. Periodontal Disease in Patients Visiting a Tertiary Care Dental Hospital: A Descriptive Cross-sectional Study...

\begin{tabular}{|c|c|c|c|}
\hline & $\begin{array}{l}\text { Female } \\
\mathrm{n}(\%)\end{array}$ & $\begin{array}{l}\text { Male } \\
\mathrm{n}(\%)\end{array}$ & Total n (\%) \\
\hline \multicolumn{4}{|c|}{ Simplified Oral Hygiene Index (OHI-S) } \\
\hline Good & $\begin{array}{l}35 \\
(19.13)\end{array}$ & $18(9.83)$ & $53(28.96)$ \\
\hline Fair & $\begin{array}{l}53 \\
(28.96)\end{array}$ & $61(33.34)$ & $114(62.30)$ \\
\hline Poor & $4(2.18)$ & $12(6.56)$ & $16(8.74)$ \\
\hline \multicolumn{4}{|c|}{ Dental visits } \\
\hline First visit & $\begin{array}{l}34 \\
(18.58)\end{array}$ & $46(25.14)$ & $80(43.72)$ \\
\hline Frequently & $\begin{array}{l}23 \\
(12.57)\end{array}$ & $8(4.37)$ & $31(16.94)$ \\
\hline Occasionally & $\begin{array}{l}35 \\
(19.13)\end{array}$ & $37(20.22)$ & $72(39.34)$ \\
\hline \multicolumn{4}{|c|}{ Tooth cleaning device } \\
\hline Toothbrush & $\begin{array}{l}92 \\
(50.27)\end{array}$ & $91(49.73)$ & $183(100)$ \\
\hline \multicolumn{4}{|c|}{ Interdental aids usage } \\
\hline Dental floss & $3(1.64)$ & - & $3(1.64)$ \\
\hline No aids & $\begin{array}{l}89 \\
(48.63)\end{array}$ & $91(49.73)$ & $180(98.36)$ \\
\hline \multicolumn{4}{|c|}{ Mouthwash usage } \\
\hline Yes & $4(2.18)$ & - & $4(2.18)$ \\
\hline No & $\begin{array}{l}88 \\
(48.09)\end{array}$ & $91(49.73)$ & $179(97.82)$ \\
\hline \multicolumn{4}{|c|}{ Type of brush } \\
\hline Hard & $3(1.64)$ & $6(3.28)$ & $9(4.92)$ \\
\hline Medium & $\begin{array}{l}41 \\
(22.40)\end{array}$ & $65(35.52)$ & $106(57.92)$ \\
\hline Soft & $\begin{array}{l}48 \\
(26.23)\end{array}$ & $20(10.93)$ & $68(37.16)$ \\
\hline \multicolumn{4}{|c|}{ Dentifrice type } \\
\hline Fluoridated & $\begin{array}{l}90 \\
(49.18)\end{array}$ & $90(49.18)$ & $180(98.36)$ \\
\hline Non-fluoridated & $2(1.09)$ & $1(0.55)$ & $3(1.64)$ \\
\hline \multicolumn{4}{|c|}{ Brushing methods } \\
\hline $\begin{array}{l}\text { Scrub } \\
\text { (horizontal) }\end{array}$ & $\begin{array}{l}90 \\
(49.18)\end{array}$ & $90(49.18)$ & $180(98.36)$ \\
\hline Circular & $2(1.09)$ & $1(0.55)$ & $3(1.64)$ \\
\hline
\end{tabular}

\begin{tabular}{|c|c|c|c|}
\hline \multicolumn{4}{|c|}{ Brushing frequency } \\
\hline Once per day & $\begin{array}{l}56 \\
(30.60)\end{array}$ & $71(38.80)$ & $127(69.40)$ \\
\hline Twice daily & $\begin{array}{l}35 \\
(19.13)\end{array}$ & $18(9.83)$ & $53(28.96)$ \\
\hline Occasionally & $1(0.55)$ & $2(1.09)$ & $3(1.64)$ \\
\hline \multicolumn{4}{|c|}{ Smoking habits } \\
\hline Current smoker & $3(1.64)$ & $32(17.49)$ & $35(19.13)$ \\
\hline Former smoker & $2(1.09)$ & $9(4.92)$ & $11(6.01)$ \\
\hline Non-smoker & $\begin{array}{l}87 \\
(47.54)\end{array}$ & $50(27.32)$ & $137(74.86)$ \\
\hline \multicolumn{4}{|c|}{ Form of smoking } \\
\hline Cigarettes & $5(2.73)$ & $41(22.40)$ & $46(25.14)$ \\
\hline \multicolumn{4}{|c|}{ Education } \\
\hline Illiterate & $7(3.83)$ & $5(2.73)$ & $12(6.56)$ \\
\hline $\begin{array}{l}\text { Primary and } \\
\text { upper primary } \\
\text { (grade 1-8) }\end{array}$ & $1(0.55)$ & $5(2.73)$ & $6(3.28)$ \\
\hline $\begin{array}{l}\text { Secondary } \\
\text { and higher } \\
\text { secondary } \\
\text { (grade 9-12) }\end{array}$ & $\begin{array}{l}54 \\
(29.51)\end{array}$ & $32(17.49)$ & $86(46.99)$ \\
\hline $\begin{array}{l}\text { Bachelors and } \\
\text { above }\end{array}$ & $\begin{array}{l}30 \\
(16.39)\end{array}$ & $49(26.78)$ & 79 (43.17) \\
\hline \multicolumn{4}{|c|}{ Occupation } \\
\hline Army & - & $3(1.64)$ & $3(1.64)$ \\
\hline Business & $4(2.18)$ & $15(8.20)$ & $19(10.38)$ \\
\hline $\begin{array}{l}\text { Creative and } \\
\text { sports }\end{array}$ & $3(1.64)$ & $2(1.09)$ & $5(2.73)$ \\
\hline $\begin{array}{l}\text { Health and } \\
\text { social worker }\end{array}$ & $9(4.92)$ & $4(2.18)$ & $13(7.10)$ \\
\hline Hospitality & - & $4(2.18)$ & $4(2.18)$ \\
\hline Manual worker & - & $13(7.10)$ & $13(7.10)$ \\
\hline $\begin{array}{l}\text { Service (govt. } \\
\text { and private, } \\
\text { white collar) }\end{array}$ & $6(3.28)$ & $26(14.21)$ & $32(17.49)$ \\
\hline Student & $\begin{array}{l}31 \\
(16.94)\end{array}$ & $17(9.29)$ & $48(26.23)$ \\
\hline Unemployed & $\begin{array}{l}39 \\
(21.31)\end{array}$ & $7(3.83)$ & $46(25.14)$ \\
\hline Total & $\begin{array}{l}92 \\
(50.27)\end{array}$ & $91(49.73)$ & $183(100)$ \\
\hline
\end{tabular}

\begin{tabular}{|c|c|c|c|c|c|c|c|c|c|c|c|}
\hline \multirow{2}{*}{$\begin{array}{l}\text { Table } 5 \\
\text { Age } \\
\text { (years) }\end{array}$} & \multirow{2}{*}{ n (\%) } & \multirow[t]{2}{*}{ Sex } & \multirow[t]{2}{*}{ n (\%) } & \multicolumn{2}{|l|}{ CPI } & \multicolumn{2}{|l|}{ LOA } & \multicolumn{2}{|l|}{ OHI-S } & \multicolumn{2}{|l|}{ BMI } \\
\hline & & & & Mean $\pm S D$ & SEM & $\begin{array}{l}\text { Mean } \pm \\
\text { SD }\end{array}$ & SEM & $\begin{array}{l}\text { Mean } \pm \\
\text { SD }\end{array}$ & SEM & $\begin{array}{l}\text { Mean士 } \\
\text { SD }\end{array}$ & SEM \\
\hline \multirow[t]{2}{*}{$\leq 35$} & $\begin{array}{l}100 \\
(54.64)\end{array}$ & Female & 57 (31.15) & $1.74 \pm 0.75$ & 0.09 & $\begin{array}{l}0.35 \pm \\
0.58\end{array}$ & 0.07 & $\begin{array}{l}1.23 \pm \\
0.77\end{array}$ & 0.10 & $\begin{array}{l}21.17 \pm \\
2.97\end{array}$ & 0.39 \\
\hline & & Male & $43(23.50)$ & $2.12 \pm 0.59$ & 0.08 & $\begin{array}{l}0.56 \pm \\
0.55\end{array}$ & 0.08 & $\begin{array}{l}1.62 \pm \\
0.81\end{array}$ & 0.12 & $\begin{array}{l}23.34 \pm \\
2.70\end{array}$ & 0.41 \\
\hline
\end{tabular}


Dhami et al. Periodontal Disease in Patients Visiting a Tertiary Care Dental Hospital: A Descriptive Cross-sectional Study...

\begin{tabular}{|c|c|c|c|c|c|c|c|c|c|c|c|}
\hline \multirow[t]{2}{*}{36 to 55} & \multirow[t]{2}{*}{$\begin{array}{l}60 \\
(32.79)\end{array}$} & Female & $27(14.75)$ & $2.15 \pm 0.53$ & 0.10 & $\begin{array}{l}0.67 \pm \\
0.62\end{array}$ & 0.11 & $\begin{array}{l}1.82 \pm \\
0.66\end{array}$ & 0.12 & $\begin{array}{l}25.55 \pm \\
3.39\end{array}$ & 0.65 \\
\hline & & Male & $33(18.03)$ & $2.21 \pm 0.65$ & 0.11 & $\begin{array}{l}0.94 \pm \\
0.61\end{array}$ & 0.10 & $\begin{array}{l}2.02 \pm \\
0.98\end{array}$ & 0.17 & $\begin{array}{l}24.95 \pm \\
1.94\end{array}$ & 0.33 \\
\hline \multirow[t]{5}{*}{$\geq 56$} & \multirow[t]{4}{*}{$\begin{array}{l}23 \\
(12.57)\end{array}$} & Female & $8(4.37)$ & $2.00 \pm 0.54$ & 0.19 & $\begin{array}{l}1.25 \pm \\
0.46\end{array}$ & 0.16 & $\begin{array}{l}2.07 \pm \\
0.51\end{array}$ & 0.18 & $\begin{array}{l}26.45 \pm \\
4.55\end{array}$ & 1.60 \\
\hline & & Male & $15(8.20)$ & $2.60 \pm 0.74$ & 0.19 & $\begin{array}{l}1.47 \pm \\
0.74\end{array}$ & 0.19 & $\begin{array}{l}2.30 \pm \\
1.10\end{array}$ & 0.28 & $\begin{array}{l}25.36 \pm \\
4.41\end{array}$ & 1.13 \\
\hline & & Female & $92(50.27)$ & $1.88 \pm 0.69$ & 0.07 & $\begin{array}{l}0.52 \\
\pm 0.64\end{array}$ & 0.06 & $\begin{array}{l}1.47 \pm \\
0.78\end{array}$ & 0.81 & $\begin{array}{l}22.92 \pm \\
3.92\end{array}$ & 0.40 \\
\hline & & Male & 91 (49.73) & $2.23 \pm 0.65$ & 0.06 & $\begin{array}{l}0.85 \\
\pm 0.68\end{array}$ & 0.07 & $\begin{array}{l}1.88 \pm \\
0.95\end{array}$ & 0.09 & $\begin{array}{l}24.25 \pm \\
2.92\end{array}$ & 0.30 \\
\hline & \multicolumn{2}{|l|}{ Total } & $183(100)$ & $2.05 \pm 0.69$ & 0.05 & $\begin{array}{l}0.68 \pm \\
0.68\end{array}$ & 0.05 & $\begin{array}{l}1.67 \pm \\
0.89\end{array}$ & 0.06 & $\begin{array}{l}23.58 \pm \\
3.52\end{array}$ & 0.25 \\
\hline
\end{tabular}

The mean BMI score was 23.58 \pm 3.52 (SEM $=0.26$; minimum = 16.66; maximum $=38.27)$ with $113(61.75 \%)$ participants of normal weight (18.5 to 24.9) forming the majority, while $55(30.05 \%)$ were overweight, 8 $(4.37 \%)$ underweight and $7(3.83 \%)$ obese. When the $\mathrm{BMI}$ scores and periodontal status were compared, the mean values of $\mathrm{BMI}$ were seen to increase with increasing $\mathrm{CPI}$, LOA and OHI-S scores.

Majority of the study participants $(137,79.4 \%)$ were non-smokers (Table 2). The form of smoking among smokers was found to be exclusively cigarettes. When smoking status was compared with CPI, LOA and OHI-S scores, periodontal and oral hygiene status was seen to be better in non-smokers (CPI $=1.97 \pm 0.69$; LOA = $0.55 \pm 0.62 ; \mathrm{OHI}-\mathrm{S}=1.52 \pm 0.84$ ), but not much difference was appreciated among current $(\mathrm{CPI}=2.20 \pm 0.58$; LOA $=1.03 \pm 0.71 ; \mathrm{OHI}-\mathrm{S}=2.12 \pm 1.00)$ and former smokers $(\mathrm{CPI}=2.64 \pm 0.67 ; \mathrm{LOA}=1.27 \pm 0.65 ; \mathrm{OHI}-\mathrm{S}=2.14 \pm 0.36)$. Smoking status and sex also showed positive relation with more male smokers in both current as well as former smoker categories (Table 2).

The mean age of the population was $36.37 \pm 14.43$ years $(\mathrm{SEM}=1.067$, minimum 16 years, maximum 72 years) of which most were either students 48 $(26.23 \%)$ or unemployed 46 (25.14\%). The education level "secondary and higher secondary" category had majority 86 (46.99\%) of the participants followed by "bachelors and above" category (Table 2). Of all participants, $34(18.58 \%)$ suffered from cardiac diseases, 16 (8.74\%) had diabetes, 1 (0.54\%) had gastrointestinal disorder and $3(1.63 \%)$ had thyroid disorders. In total, $133(72.68 \%)$ reported no underlying systemic condition.

\section{DISCUSSION}

Oral diseases mainly the periodontal disease and dental caries are one of the commonest chronic diseases affecting mankind. In the past, diseases of the oral cavity have been viewed separately from those of the rest of the body. However, in recent years, efforts have been made to recognise oral health as an integral component of general health. Healthy teeth along with its supporting structure, the periodontium is vital for the maintenance of teeth in oral cavity and thus important for oral health. The initial stage gingivitis progresses in a sequential manner towards periodontitis ultimately resulting in tooth loss. Thus, if oral health diseases can be identified at an early stage, tooth loss can be prevented. The causes for tooth loss: periodontal disease and dental caries, both are entirely preventable by regular oral hygiene maintenance.

Though it is well-known and often advocated that practising just simple measures of oral hygiene like brushing twice daily with soft-bristle toothbrush, fluoridated toothpaste, using interdental aids, and visiting the dentist twice a year for regular check-up and oral prophylactic treatment can reduce tooth loss drastically, individuals seldom practise so. The present study provides information on oral hygiene status, oral hygiene practices and periodontal health of 183 people of age above 15 years visiting a tertiary care dental hospital.

Oral hygiene status was found to be "fair" in most of the population 114 (62.30\%). This was similar to study by Bhattarai et al., ${ }^{14}$ Umoh and Azodo ${ }^{6}$ and Olabisi et al. ${ }^{15}$ The high values of the oral hygiene index and its components (debris and calculus indices) suggest a neglect of tooth cleaning and oral health awareness. It is further supported by the frequency of dental visits by the population. For most of the sample population it was their first dental visit $80(43.72 \%)$. This is in contrast to Bhattarai et al. who reported $65.5 \%$ had 
visited a dentist before. ${ }^{14}$ The frequency of brushing was reported "once daily" by most. This is similar to findings of Baishya et al. ${ }^{8}$ Asgari et al. ${ }^{16}$ El Bcheraoui et al. ${ }^{17}$ and Shah and ElHaddad. ${ }^{18}$ Majority did not use dental floss or other interdental aids, similar to the same studies. ${ }^{16-18}$ Despite advocacy by dentists and related organisations to brush twice daily and use interdental aids, the individuals do not seem motivated enough to practice that. The tooth cleaning devices were exclusively toothbrushes and toothpastes where $180(98.36 \%)$ of the subjects used fluoridated toothpaste. This is in contrast with the study of Pradhan et al. ${ }^{5}$ where the sample population used several other tooth cleaning methods including finger, twig, tooth powder, charcoal, ash, sand and tobacco but similar to Bhattarai et al. ${ }^{14}$ The sample population in Pradhan et al. was rural whereas Bhattarai et al. was urban like present study. Though scrub (horizontal) brushing technique is not recommended by dentists, it was the technique preferred by the participants 180 (98.4\%). It could be due to convenience and lack of knowledge regarding better brushing techniques like modified Bass, modified Stillman, etc.

In the present study, healthy periodontal condition CPI 0 was found only in $2(1.09 \%)$ and LOA 0 in 79 $(43.17 \%)$ of the examined individuals indicating the presence of gingival disease in 136 (74.32\%) and periodontal disease in 104 (56.83\%) participants. This is in consonance with other studies. ${ }^{4,5,19-21}$ Calculus (Code 2) and shallow pocket (Code 3) were the most frequently observed conditions followed by bleeding on probing (Code 1). , $13,19-23$ Lack of oral health awareness and negligence from people could be the factors responsible for this even though the study was conducted in urban population.

The number of healthy sextants decreased with advancing age which is in accordance with available literature reporting increasing age with increasing severity of periodontitis. 2,3,7,8,21,22,24 About "Education", majority of the sample were secondary and higher secondary above. One reason could be because of lack of oral health awareness in less educated individuals, they don't go to dental hospital unless they have to. Some epidemiological studies have shown positive association between BMI and periodontitis while others have not. ${ }^{24}$ The current study also showed higher BMI scores with worsening oral and periodontal status.

Though, periodontal status and oral hygiene status were observed to be better in non-smokers, similar to other studies, most 137 (79.4\%) of the study participants were non-smokers. ${ }^{2,17,18,24}$ Study with equally distributed participants would show more accurate finding. As smoking is considered a taboo or adverse habit in a society like ours, the participants may not have reported the true smoking status. ${ }^{24}$ Female participants showed better oral hygiene practices and better oral and periodontal health. This is similar to other studies within Nepal and abroad. 2,7,15,16,19,21 This could be because of female individuals being more concerned regarding oral hygiene and visit dentist more often. Male also have other deleterious habits like smoking cigarette, chewing pan/tobacco, taking gutkha, that negatively affect oral health. Smoking status and sex also showed positive association with more male smokers both current as well as former similar to Gupta et al. ${ }^{2}$ Dahal et al. ${ }^{7}$ and Kundu et al. ${ }^{21}$ The result may not be accurate because due to social disparities, the female smokers may not have reported truthfully.

The present study showed a high prevalence of gingival disease, calculus and shallow pockets in the examined population which indicate that the oral hygiene methods employed and the frequency of dental visits by the population are not adequate or effective enough. As the updated information on oral and periodontal health of Nepali adults is limited, this assessment would be helpful to national policy makers on oral health and intervention measures to prevent periodontal diseases and develop future programs to improve oral health.

The limitations are: since the $\mathrm{CPI}$ and $\mathrm{OHI}-\mathrm{S}$ measurements were done only in the index teeth, it can overestimate or underestimate the prevalence of periodontal disease and oral hygiene status respectively. Similarly, the relation between method of cleaning teeth, pack years of smoking, oral hygiene status, and periodontal disease were not considered. Other limitations include: it was a single-centre observational study with small sample size and short duration. Hence multi-centre studies with larger sample size would give more accurate representation of periodontal status and factors affecting the periodontal health in Nepalese population.

\section{CONCLUSIONS}

In current study, more than half of the participants had periodontal disease. The findings also suggest a positive relation of deteriorating oral and periodontal health status with age, sex, oral hygiene practice, poor oral habits (like smoking), and BMI. A very low priority is placed upon its prevention and treatment due to relatively low mortality and morbidity compared to other diseases and other factors like knowledge, cost, availability, and accessibility of services. Though, there is an upward trend in attending clinics and hospital facilities in urban areas, the result shows that there is a need to give more attention to periodontal disease. Emphasis on brushing twice daily with soft- 
bristled toothbrush and fluoridated toothpaste, usage of interdental aids and visiting a dentist twice a year is still lacking.

In order to achieve ideal oral health status and periodontal health, appropriate preventive and periodic periodontal therapies should be provided. Also, to bring down the prevalence of periodontal diseases to decrease the tooth loss and improve the oral health related quality of life, special emphasis should be given on oral health education and motivation both from government as well as private sectors.

\section{ACKNOWLEDGEMENTS}

We acknowledge the support and motivation from Dr. Sirjana Dahal, Dr. Swechchha Pokhrel, the Department of Community and Public Health Dentistry, Kantipur Dental College and first year students of Certificate in Dental Science of Kantipur School of Dentistry. Last not the least, heartfelt gratitude to all the patients who volunteered to participate in this study.

\section{Conflict of Interest: None.}

\section{REFERENCES}

1. Khapung A, Rao GN, Shrestha S, Dhami B, Gupta S. Periodontal status and oral health-related quality of life among elderly attending Kantipur dental college, Kathmandu, Nepal. J Nepal Soc Perio Oral Implantol. 2017 Jul-Dec;1(2):46-50. [Full Text | DOI]

2. Gupta S, Maharjan A, Dhami B, Amgain P, Katwal S, Adhikari B, et al. Status of tobacco smoking and diabetes with periodontal disease. J Nepal Med Assoc. 2018 Sep-Oct;56(213):818-24. [PubMed | Full Text | DOI]

3. Humagain M, Adhikari S. Assessment of periodontal status of the people in Chepang hill tract of Nepal: A cross sectional study. Kathmandu Univ Med J (KUMJ). 2018 Jul-Sep;16(63):206-10. [uㅏㄹed | Full Text]

4. Dhami B, Shrestha P, Kamath DG, Mahesh CP, Uppoor A, Nayak DG. Assessment of periodontal health status using community periodontal index (CPI) in a rural population of Nepal. J Nepal Dent Assoc. 2012 Jan-Jun;12(1):1-9. [Full Text]

5. Pradhan S, Bhat MK. Assessment of periodontal status of rural Nepalese population using the community periodontal index. J Nepal Dent Assoc. 2009;10(2):97-104. [Full Text]

6. Umoh AO, Azodo CC. Association between periodontal status oral hygiene status and tooth wearing among adult male population in Benin City, Nigeria. Ann Med Health Sci Res. 2013;3(2):149-54. [PubMed | Full Text | DOI]

7. Dahal S, Poudel P, Khadka N, Dahal S, Acharya M, Shrestha $S$, et al. Attitude, behavior and oral health among patients visiting a dental institution of Nepal. J Coll Med Sci Nepal. 2020 Jan-Mar;16(1):44-8. [Full Text | DOI]

8. Baishya B, Satpathy A, Nayak R, Mohanty R. Oral hygiene status, oral hygiene practices and periodontal health of brick kiln workers of Odisha. J Indian Soc Periodontol. 2019 Mar-Apr;23(2):163-7. [uㅏMed | Full Text | DOI]

9. World Health Organization. Oral Health Surveys: Basic Methods. 4th ed. Geneva: World Health Organization; 1997. [Full Text]

10. Greene JC, Vermillion JR. The simplified oral hygiene index. J Am Dent Assoc. 1964 Jan;68:7-13. [uㅐㄹ | Full Text | $\underline{\mathrm{DOI}}]$
11. Flegal KM, Kit BK, Graubard BI. Body mass index categories in observational studies of weight and risk of death. Am J Epidemiol. 2014 Aug;180(3):288-96. [마bMed | Full Text | DOI]

12. Newman MG, Takei HH, Klokkevold PR, Carranza FA, editors. Carranza's Clinical Periodontology - A South Asia Edition. 11th ed. New Delhi, India: Saunders, Elsevier; 2011. [Full Text]

13. Grewal Y, Datta R, Singh K, Singh G, Singh S, Kaur P. Prevalence of periodontal disease in the rural population of Punjab, India. J Pharm Biomed Sci. 2014;4(6):532-5. [Full Text]

14. Bhattarai R, Khanal S, Rao GN, Dhami B, Gupta S. Oral hygiene and periodontal health status of urban population of Kathmandu district: a pilot study. J Nepal Soc Perio Oral Implantol. 2017 Jan-Jun;1(1):12-6. [Full Text | DOI]

15. Olabisi AA, Udo UA, Ehimen UG, Bashiru BO, Gbenga OO, Adeniyi AO. Prevalence of dental caries and oral hygiene status of a screened population in Port Harcourt, Rivers State, Nigeria. J Int Society Prev Community Dent. 2015 Jan-Feb;5(1):59-63. [

16. Asgari F, Majidi A, Koohpayehzadeh J, Etemad K, Rafei A. Oral hygiene status in a general population of Iran, 2011: a key lifestyle marker in relation to common risk factors of non-communicable diseases. Int J Health Policy Manag. 2015 Jan 30;4(6):343-52. [uued | Full Text | DOI]

17. El Bcheraoui C, Tuffaha M, Daoud F, Kravitz H, AlMazroa MA, Al Saeedi M, et al. Use of dental clinics and oral hygiene practices in the Kingdom of Saudi Arabia, 2013. Int Dent J. 2016 Apr;66(2):99-104. [uuMed | Full Text | DOI]

18. Shah AH, ElHaddadSA. Oral hygiene behavior, smoking, and perceived oral health problems among university students. J Int Soc Prev Community Dent. 2015 Jul-Aug;5(4):327-33. [PubMed | Full Text | DOI]

19. Bansal M, Mittal N, Singh TB. Assessment of the prevalence of periodontal diseases and treatment needs: A hospital-based study. J Indian Soc Periodontol. 2015 Mar-Apr;19(2):211-5.

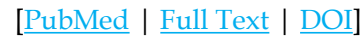


Dhami et al. Periodontal Disease in Patients Visiting a Tertiary Care Dental Hospital: A Descriptive Cross-sectional Study...

20. Vano M, Gennai S, Karapetsa D, Miceli M, Giuca MR, Gabriele M, et al. The influence of educational level and oral hygiene behaviours on DMFT index and CPITN index in an adult Italian population: an epidemiological study. Int J Dent Hyg. 2015 May;13(2):151-7. [PubMed | Full Text | DOI]

21. Kundu D, Mehta R, Rozra S. Periodontal status of a given population of West Bengal: An epidemiological study. J Indian Soc Periodontol. 2011 Apr;15(2):126-9. [P Full Text | DOI]

22. Saribas E, Kaya FA, Dogru AG, Yildirim TT. Determination of periodontal status and smoking habits with CPITN index. Int Dent Res. 2017;7(2):26-31. [Full Text | DOI]

23. Budiman AF. The increase of periodontal tissue in type 2 diabetes mellitus patients based on index CPITN. J Kesehat Masy. 2016 Jul;12(1):18-24. [Full Text | DOI]

24. Gupta S, Pradhan S, Kc S, Shakya S, Giri M. C-reactive Protein in Periodontitis and its Comparison with body mass index and smoking behaviour. J Nepal Med Assoc. 2017 Apr-Jun;56(206):226-33. [ㅁubMed | Full Text | DOI]

This work is licensed under a Creative Commons Attribution 4.0 International License. The images or other third party material in this article are included in the article's Creative Commons license, unless indicated otherwise in the credit line; if the material is not included under the Creative Commons license, users will need to obtain permission from the license holder to reproduce the material. To view a copy of this license, visit http://creativecommons.org/licenses/by/4.0/ 